\section{Scottish science and devolution}

\author{
Martin Goldman looks at possible effects \\ of devolution on science in Scotland
}

$\mathrm{F}_{\mathrm{k}}^{\mathrm{A}}$ CED with the present media overkill of the devolution debate, more and more Scots are displaying a traditionally 'British' response to the issue -apathy. At the risk of increasing the tendency, Scottish science deserves special attention, for the problem of reconciling the international horizons of science with the nationalist viewpoint is of wider relevance, even though it is still largely theoretical. The Scottish National Party, the spearhead of the independence movement, has not yet needed to produce a concrete science policy. They have not decided whether nuclear power is an invention 'o'er the de'il', much less what role it would play in an overall energy strategy, and have not even considered whether or how to continue as members of CERN.

More positive has been the concern of academics. A strong feeling against the devolution of Scottish universities was displayed in response to a questionnaire sent out by the Scottish Association of University Teachers. About $60 \%$ of the replies disapproved of devolution: $20 \%$, approved, 20\% were neutral.

A paper on the whole subject presented to the government by Professor John Gunn, a theoretical physicist, and Andrew Thomson, an economist, gives the consensus view. They feel that universities ought to be international in outlook, and therefore anything hindering communications between British universities, especially the easy exchange of staff and students, is a bad thing. The decline of the international reputation of Trinity College, Dublin. since Irish independence is an example.

Their other major argument is that there exist economies of scale. Each university department has particular areas where it focuses its attention; Scottish universities do not cover a complete academic spectrum and are overproductive in certain areas (for example, Scotland, with $10 \%$ of the UK population, produces 150 vets a year out of a UK total of 350). Because of the expense of equipment, particularly in the sciences, and the existence of critical thresholds on the size of department, below which useful research is not done, such specialisation makes good sense.

In addition to these general arguments, they add that the present funding system, through the Universities Grants Committee (UGC) and various research councils, works well in that it allows a large degree of autonomy to the universities. If a Scottish UGC were created, it would be a cosier affair than the British one, and inevitable incestuous relationships' would ensue. Equally dreaded would be the alternative of integration with the Scottish Educational Department (SED) responsible for the present Scottish educational system. Universities are, of necessity, elitist organisations and are afraid they would be swamped if included with other forms of education. In addition the track record of the SED is appalling. In spite of (or because of?) a new newmaths syllabus, there has been a catastrophic disintegration of mathematical education in Scotland. All Scottish university science departments complain bitterly of the mathematical illiteracy of incoming students -the educational elite, no less-who cannot cross-multiply fractions, know no trigonometry, and require remedial courses to teach them basic skills.

\section{Dissenting view}

These views contrast strongly with those of both the SNP and the Scottish Union of Students. At the same time as Gunn and Thomson argued their case, Professor R. S. Silver, an internationally renowned expert on desalination and a life-long nationalist, presented a dissenting view. On the 'internationalist' argument, he contends that other small countries such as Holland and Israel have solved the problem. An independent Scotland would be forced to look out more to the world. He repudiates the inevitability of incestuous relationships, arguing that if this were so, then conversely Russia and China would have the fairest support system in the world. Professor Silver also points out that estrangement will inevitably arise under the present proposals between the institutes of technology (contrclled from Edinburgh) and the universities (controlled from London). As for the economy of scale argument, he thinks that 'big science' has already grown too big. It leads to massive engineering projects that are socially destructive and tie together the world's economies in an unstable manner, like a house of cards.

Since then the debate has descended to the letter columns of The Scotsman and the THES. John Hulbert, prospective SNP MP and former lecturer in bacteriology at the University of Dundee, has waded in with his analysis.

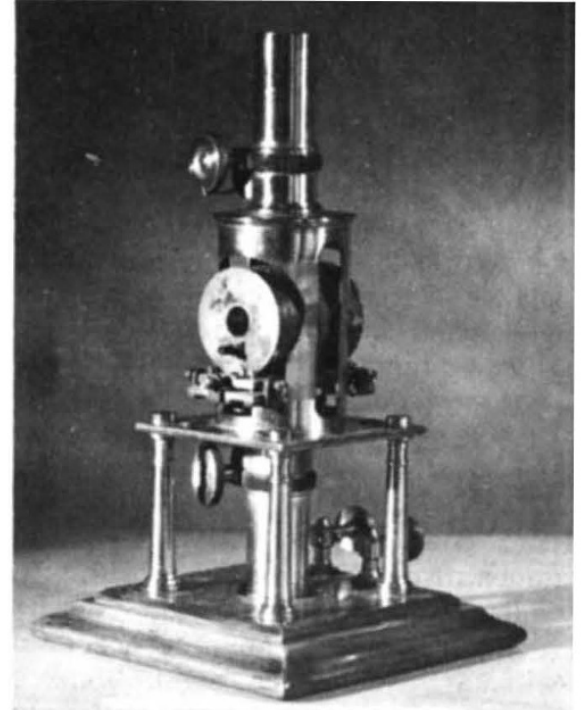

Produce of Scotland:

Kelvin's mirror galvanometer

He finds it 'sinister' that since 1939 the proportion of professors in Scotland with a Scottish education has dropped from 73 ". to $48 \%$. Remembering that Scotland has only $10 \%$ of the UK population, most would find this evidence of continued parochialism, and his views an unhappy auguration of future SNP thinking on the 'internationalism' of Scottish universities.

To Professor Malcolm Slesser of the energy studies department of Strathclyde University, who is also a nationalist, this idea of 'technological ecology' is also central. Engineering should be on an appropriate, human scale, and vast expensive projects should be eschewed. He, for one, would not complain if an independent Scotland could not build the Concorde. Silver and Slesser's argument is weakened by the fact that whatever the final scale of a project, the cost of developing even appropriate technologies is now vast, as exemplified by the programmes afoot in the USA, France and Japan to utilise solar power. Equally, almost no science is conceivable nowadays without a big computer. How big a computer could Scotland afford?

Professor Slesser thinks the real problem of Scotland stems from a lack of financial support for the development of appropriate new technology. $\mathrm{He}$ would like to see a revival of the technological entrepreneurship that characterised nineteenth century Scottish science, when a scientist such as Lord Kelvin could make a fortune (and get knighted) from his inventions. An investigation of government spending supports his view. Scotland does get a fair share of the UGC's and the research councils' university spending. The research councils also support speciai units: the MRC supports many all over the UK, and Scotland does 
rather well, with 11 of these. The MRC works on the human scale, however; the SRC, which is responsible for 'big science', believes it has to have its expensive equipment housed in central facilities, shared by the country as a whole. This argument is rather damaged by the fact that its major 'centre', consisting of the Rutherford Laboratory (particle physics), the Culham Laboratory (plasma physics), the National Computer Laboratory, the High Power Laser Facility and the Appleton Laboratory (space and atmospheric research), is very conveniently situated for London, but is well south of the academic centre of the UK, which is strongly weighted by the Northern and Scottish universities.

This is a mere peccadillo compared to the policy of the biggest research spender of the country, the Ministry of Defence. Of the 45 major research establishments listed by the MOD, apart from the lonely Naval Construction Research Establishment in Dunfermline, none are farther north than Baldock, 35 miles from London. As part of the devolution package the government has promised to move the MOD to Glasgow, which has a chronic unemployment problem. Every few weeks Glaswegians read in their newspapers, with a mixture of anger and amusement, the ideas of civil servants on the putative great trek North. The most common view seems to be that civilisation stops at Chingford and the Arctic Circle begins at Watford Gap.
Hopefully, if the MOD is ever moved it will learn the error of its views and devolve some of its research establishments also.

\section{Eternal drawback}

What, then, about industrial research? While the government tries to encourage industry to the North with various short term benefits, there is an eternal drawback in that Scotland is at the periphery of Europe, and transport costs must always be high. This adds about $£ 50$ to the cost of a car made in Scotland rather than Birmingham. The more valuable the basic product, however, the less significant are these transport costs, and thus factories producing high technology items are least affected. This has been recognised by the American computer giants, and Honeywell, IBM, NCR, and Hewlett Packard all have factories in Scotland. They are just factories, however, and the best Scottish managerial and research personnel are siphoned off to England or abroad. Could the process be reversed by independence? This seems doubtful, in that a small Scotland is unlikely to be more successful at dealing with a high-technology multinational than the $\mathrm{UK}$ as a whole.

The lack of investment in new technology is also borne out by the experiences of the National Engineering Laboratory (NEL) at East Kilbride. Seven years ago the Rothschild committee recommended that the NEL should become less academic and liaise more with industry - should become, in effect, East Kilbride's answer to MIT. To a certain extent this has worked: of an annual budget of $£ 10,000,000$, industry now contributes $£ 1,250,000$, and of NEL's marketable ideas about half are taken up by local Scottish industry-eventually. John McAllen of NEL's industrial marketing unit is, however, depressed at the lack of interest that most of industry displays in trying to identify areas where new technology could be developed. Especially depressing is the tale of NEL's hydraulically driven dumper truck. In spite of a total lack of industrial interest NEL were convinced that this idea had promise, and developed it on their own. Their perseverance paid off, and eventually Carron Hydraulics of Falkirk took out a franchise on the invention. When the potential of the idea was proved, however, Carron Hydraulics was promptly taken over by the German Rexroth group.

The story of other countries reaping the rewards from Biritish inventions is now only too familiar. The worrying aspect of this case is that the invention was developed with government money specifically to benefit British industry; safeguards against subsequent foreign takeover should have been written in. The NEL is, nevertheless, of great importance to Scotland, both as an employer of scientific personnel and as a stimulus to industry. Its status in an independent Scotland would be very doubtful.

\section{Maintaining momentum}

Colin Norman reports from

Washington on latest developments concerning recombinant DNA research

THE debate over the risks and benefits associated with recombinant DNA research, which has been raging in college campuses and city halls around the United States, suddenly picked up momentum in Washington last week. At one end of town, a public meeting sponsored by the National Academy of Sciences provided a forum for a clash of views on whether, and under what circumstances, such research should be permitted. At the other end of town, Representative Paul Rogers, chairman of the House health subcommittee, proposed legislation to regulate all recombinant DNA research in the United States. And in suburban Bethesda, a committee of officials from several government agencies met to try to draft a bill to be sponsored by the Carter Administration.
About the only clear message to emerge from this flurry of activity is that legislation to control recombinant DNA experiments throughout the United States is now inevitable, and that it would be welcomed even by many of the scientists who have long shivered at the thought of having an agency of the federal government regulate their research. But there was the glimmering of another message, at least in the Academy's public meeting. There emerged at the meeting vocal opposition to recombinant DNA research from non-scientists concerned about its potential long-term implications for human genetic engineering. Most of the debate so far has swirled around immediate health hazards, but it may slowly be shifted toward a discussion of the potential uses to which the research may ultimately be put.

First, the legislative developments. The National Institutes of Health (NIH) guidelines published last June formally apply only to recombinant DNA research supported by the federal government, and are not backed by any federal monitoring or enforcement mechanism. Industrial research is not formally regulated at present. Because of these apparent weaknesses some state and local governments are considering adopting their own enforceable regulations. Faced with that prospect, many scientists who once resisted federal legislation would now welcome it.

Whether scientists want it or not, however, legislation is definitely coming. For the past four months a task force of some 25 officials from federal agencies has been seeking ways to extend the NIH guidelines to cover all recombinant DNA research in the United States and to monitor compliance with the guidelines. The task force has recently concluded that no existing federal agency has the authority ito carry out those roles, and that new legislation is therefore needed.

The task force met last week to try to draft a bill for approval by the Secretary of Health, Education and 